\title{
Concepts and Fields of Relational Justice
}

\author{
Pompeu Casanovas ${ }^{1}$ and Marta Poblet $^{2}$ \\ ${ }^{1}$ UAB Institute of Law and Technology (IDT), Faculty of Law, Autonomous University of \\ Barcelona, Bellaterra, Barcelona-08193, Spain. http://idt.uab.cat \\ ${ }^{2}$ ICREA Researcher at the UAB Institute of Law and Technology \\ \{pompeu.casanovas, marta.poblet\}@uab.cat
}

\begin{abstract}
This paper intends to clarify the broad conceptual background of relational justice. Relational Justice (RJ) is defined as the justice produced through cooperative behavior, agreement, negotiation, or dialogue among actors in a post-conflict situation. We found concepts stemming from at least thirty different fields, going from behavioral sciences (neurology, brain sciences, primatology, social psychology, etc.) to criminology, jurisprudence, and philosophy. One of these contributing fields is Artificial Intelligence (AI), which uses several techniques to grasp the practical knowledge of negotiators and mediators and builds tools to support both negotiation and mediation processes. However, contrary to the legal ontologies field, there are no ontologies of Relational Justice yet representing the conceptual richness of the domain.
\end{abstract}

Keywords: legal concepts, legal ontologies, legal systems, dialogue, relational justice, restorative justice, ADR, ODR,

\section{Introduction}

Our focus is Relational Justice (RJ), which we define broadly as a bottom-up justice, or the justice produced through cooperative behavior, agreement, negotiation or dialogue among actors in a post-conflict situation (the aftermath of private or public, tacit or explicit, peaceful or violent conflicts). The RJ field includes ADR and ODR, mediation, victim-offender mediation (VOM), restorative justice (dialogue justice in criminal issues, for juvenile or adults), transitional justice (negotiated justice in the aftermath of violent conflicts in fragile, collapsed or failed states), community justice, family conferencing, and peace processes. ${ }^{1}$

${ }^{1}$ Only in the restorative justice field we may distinguish different separate processes and situations according to prevailing legal cultures and legal systems: community mediation programmes, victim offender reconciliation programs, victim offender mediation (VOM), conferencing, youth justice, family groups conferences in New Zealand, conferencing in Wagga Wagga (Australia), community groups, conferencing circles, Navajo justice, sentencing circles, healing circles [1]. In Europe, to consider one example, juvenile justice differs considerably as regards processes, procedures, environments, and relation with courts [2]. Differences among mediation forms and legislations are still broader [3]. 
The aim of this paper is to show the conceptual complexity of this kind of justice, which is not solely based on the application of fundamental legal concepts - norms, rules, normative systems, rights, duties, etc.- - but on both behavioral concepts from different theoretical fields and the singular, non-homogeneous experiences and practices of negotiators, facilitators, and mediators. Focus, processes and goals are therefore combined in a continuum of approaches [4].

Before any attempt to represent knowledge in a computational system or in a platform of ODR services we first need to consider the epistemological problems of knowledge acquisition. How to represent the different aspects and dimensions of experiences and practices of RJ as knowledge? How to elaborate ontologies capturing RJ knowledge? One way to proceed is to have a look on all the theoretical, scientific, and practical fields involved in the generation of relevant concepts. ${ }^{2}$ This task should be distinguished from ontology mediation (mapping, aligning and merging) [6], knowledge engineer mediation (among conflicting domain ontologies [7], or through wiki tools [8] [9]), and MAS ontology negotiation (among intelligent agents) [10].

It is worth mentioning that we are not identifying either the domains in which negotiation, mediation and ADR techniques may apply (i.e. family, real estate, environment, commerce, armed conflicts, etc.). We are focusing instead on concepts such as empathy, reciprocity, or remorse, which contribute to set up the structural frameworks to understand, explain and develop mediation and negotiation processes. We therefore propose a general overview of the theoretical and practical concepts that, emerging from both academic and professional fields, constitute conceptual kernels in the area of RJ.

\section{Concepts and fields}

We found at least thirty academic fields focusing on conflict resolution and justice. We used four criteria of identification: (i) authoring (quotations and cross-discussions and fertilization in a stable community), (ii) focus (agreement on common problems, discussion on research approaches) (iii) object (agreement on definitions, common language, conflicting theories), and (iv) methodology (comparable data, experiments or outcomes).

This meta-analysis is not entirely satisfactory and results are not homogeneous, because there are no discrete criteria to satisfy a discriminatory function, either for individuals or for collectivities. Consider, for instance, a psychologist who is both a practitioner and an academic philosopher. Similarly, we may define AI \& Law as a single academic field, or have it included into the broader field of Applied Artificial Intelligence. Choices do not go without theoretical discussions. (In the case of AI \& Law, we preferred the second option because there are many authors focusing on mediation and AI who belong to different communities).

\footnotetext{
${ }^{2}$ In this sense, this is a complementary paper to the micro-foundations for Restorative Justice that we set up in [4]. We realized that we could expand our arguments to a broader notion of justice.
} 
Moreover, shifting from restorative justice to relational justice also means to adjust our lens to a wider scope, since new theoretical fields come into play. For instance, economy and game theory (allocation of rights) play a more fundamental role in conflict resolution and management studies than in victim-offender mediation (VOM). In addition, recent developments in neuroeconomics have shown for the first time the neural foundation of social preferences, trust and social punishment [11]. As the NBIC [Nano-Bio-Info-Cogno] convergence proves [12], there is a growing interaction and synergy through scientific and technological fields.

However loose this taxonomic exercise may be, it shows the present complexity of thinking of a bottom-up justice. Micro-foundations of social behavior have already been incorporated to model agents' behavior in multi-agent systems (MAS) developments [13]. To understand social phenomena at the macro-level dimension (i.e. the functional violation of social norms or the emergence of collective properties) electronic or human agents must be conceived both with intentions, plans and goals and with the capacity to be affected by their own cognitive representations. In other words, they must incorporate an emotional dimension. At the micro-level, then, rationality and emotion cannot be conceived as opposed, but as intertwined. Fig. 1 below shows a general framework for the micro-foundations of RJ.

\subsection{From empirical to philosophical approaches}

To organize the different conceptualizations, we split up micro-foundations of RJ into four macro-domains: (i) empirical research on mind, language, forgiveness, empathy, and emotions; (ii) social research on culture, language, apologies, and micro-situations; (iii) economic, social, political and philosophical research on conflict and dialogue; and (iv) social, political, jurisprudential and philosophical research on rights and legal systems.

In this way, we start from the most empirical and fundamental research on social neuroscience (including recent trends in neuroeconomics), cognitive science, primatology, and basic social psychology (see box 1 in Fig. 1) and we draw a large intellectual bow up to the more common and general legal language of jurisprudence and ethics - rights, duties, rules, principles and norms - (box 8 in Fig. 1). The last kind of reflections may be more or less empirically grounded, may have a more or less practical or fundamental orientation, may choose a more or less literary or artificial language, may have different degrees of consistency, coherence and soundness, but they do not intend to be evaluated through the methods of normal science.

In between, we have all the specific research on conflict, dialogue, negotiation, and mediation emerged from human sciences (linguistics, anthropology, sociology, psychology, political science, economics), philosophy (logic, epistemology, argumentation), and technology (computation and artificial intelligence, including MAS and virtual or electronic institutions). 


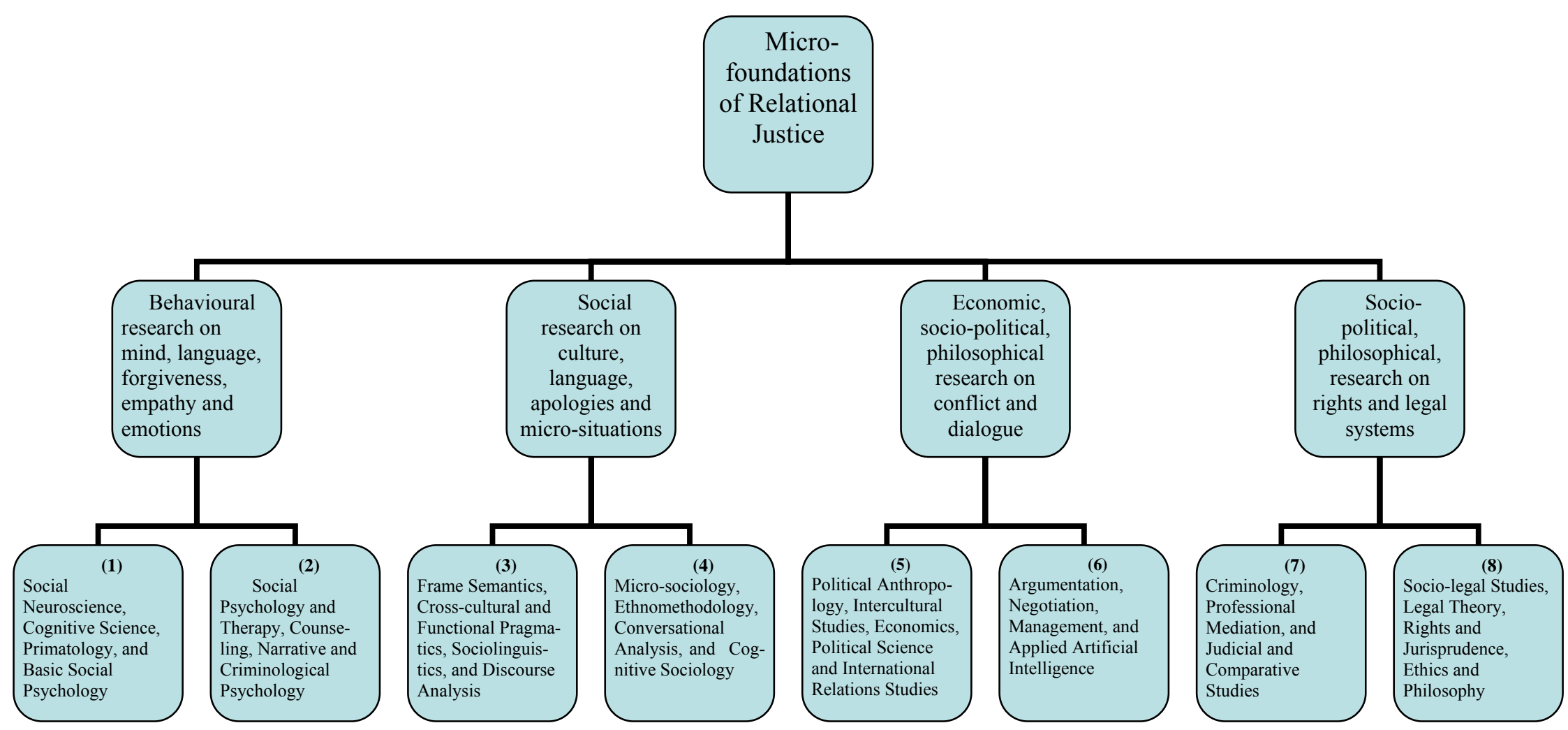

Fig. 1. A general framework for micro-foundations of Relational Justice. 


\subsection{Natural conflict resolution, aggression and conciliation patterns}

Natural Conflict Resolution [14] is the title of a well-known handbook for primatologists. The main idea is to substitute a conciliatory or cooperative pattern to the aggressive one that pioneers like Konrad Lorenz set up for natural life. From this point of view, conciliatory behavior is as 'natural' as violence. Moreover, from an evolutionary point of view, a necessary condition for survival relies on the acquisition and management of knowledge on how to handle conflicts that could diminish the capabilities of the group. "Aggression as an antisocial instinct is being replaced by a framework that considers it a tool of competition and negotiation." [15]

Empathy [Einfühlung], isopraxis (produced by mirror neurons), enaction, embodied cognition, consolation and reconciliation are some of the concepts used within the framework of a relational model of aggression. Reconciliation is considered a heuristic concept, capable of generating testable predictions about stable relationships. Protection of cooperative bonds is crucial in non-human primates with social experience and triadic relations. Humans experience the same physiological changes participating in conversation and watching it later in a video. Mind reading, making attributions about the mental states (desires, beliefs, intentions) of others, may be conceptualized as a different cognitive process than empathy. Empathy means sharing feelings and emotions in absence of any direct stimulation to themselves. Aureli considers it a kind of intervening variable, an epistemic construct used to explain complex webs of variables.

There is a strong debate on the ultimate bases of empathy and the theory of mind lying behind it [16]. ${ }^{3}$ Yet, neurological bases for shared pain between loved couples, e.g., have been detected by functional Magnetic Imaging Ressonance (fMIR) experiments ${ }^{4}$, and social neuroeconomics takes advantage from it interpreting brain activations involved in altruistic, fair and trusting behavior. The self-interest hypothesis assumed by classical behavioral sciences is being replaced instead by the idea of strong reciprocity in cooperative behavior [19].

Empathy plays a fundamental role in empirical psychological studies on forgiveness (and unforgiveness) as well. Pre-offence closeness, apology, sincerity, memory, rumination, anger, shame, avoidance, revenge, current closeness, are some of the variables taken into account in experimental models. There are several models in the literature relating to individual, family and social behavior. ${ }^{5}$ But all of them

${ }^{3}$ The Perception-Action Model (PAM), by de Waal and others, is grounded in the idea that perception and action share a common code of representation in the brain [16]. The Somatic Markers Hypothesis (SMH) by Damasio and others contends that bio-regulatory signals, including those that constitute feelings and emotion, provide the principal guide for decisions [17].

${ }^{4}$ Tania Singer experiments on wives observing their husband's pain show that there are strong anatomical connections between regions constituting the pain matrix, and this leads to the suggestion that these regions are highly interactive [18].

${ }^{5}$ Forgiveness is a well-trodden path in social and family psychology. There are relational models based in prototypes, narratives, interactions, flows and regression analysis [5] [20] [21]. 
tend to emphasize the relational nature of variables and the importance of emotions in concepts such as innocence, guilt and remorse. Social meaning and concepts contribute to trigger feelings and emotions. However, there is no agreement yet on the composition of basic or primary emotions (fear, joy, disgust, rage and surprise) [22].

\subsection{The role of culture and language in interaction patterns}

Micro-situations have been mainly analyzed by linguists and sociologists. Framesemantics, cognitive linguistics, cross-cultural pragmatics, functional pragmatics, sociolinguistics, corpus-based, and discourse analysis have contributed to have a better knowledge of the elements, structure, processes, and functions of linguistic interactions.

Some of the notions involved share a common tradition in linguistics and philosophy of language: i.e. locutionary and illocutionary acts, speech acts, events, context, competence, indexing, reference, co-reference. Others have been developed in parallel with cognitive science and AI: the notions of script, schema, slot, prototype, frame, framing, reframing, mental space, semantic field, semantic space, mental model [23] e.g. And, still, other concepts have been used along with new logical trends in philosophy: inference, inferencing, entailment, presupposition, natural and non-natural meaning, conventional implicature, conversational implicature [24]. Finally, a few of them have been developed through the empirical analysis of linguistic interactions or reflection on the phenomenology of speech: sociolects, idiolects, contextual cues, diglossia, deixis, turn-taking, adjancy-pairs, switching codes, sociolinguistic competence, face-threatening acts [FTAs] [25] [26].

More specifically, stemming from this tradition, cross-cultural pragmatic research has focused on the linguistic content and expression of politeness, apologies and excuses in different natural languages and cultures [27]. There are different existing frameworks to analyze them. Researchers have used three main paradigms to situate their analysis: (i) the 'maxims model' (Leech, Lakoff), (ii) the 'conversation contract model' (Fraser and Nolen) (iii) and the 'relevance theory model' (Sperber and Wilson) [5].

Ethnometodology, cognitive sociology, conversation analysis and micro-sociology have tried to grasp the way in which language, expression, and thought are combined in a situated meaning and in a situated, shared, tacit and socially distributed knowledge. ${ }^{6}$ Some of their originally ideas, figured out in the reaction against functionalism in the fifties and sixties, have been useful to develop later more precise cognitive and computer science applications, e.g. the Parallel Distributed Processing model [28] or the Situated Cognition model [29].

It is worth saying too that pragmatic analyses sometimes offer non conclusive results. The notions of gender language and gender speech, for instance, remain

\footnotetext{
${ }^{6}$ E. Gofmann, H.Garfinkel, A. Cicourel, R, T.Scheff and S. Retzinger are some of the names contributing to the qualitative analysis tradition in conflict and negotiation. In spite of the differences among them, they all share a detailed micro-analysis approach.
} 
controversial. ${ }^{7}$ Nevertheless, pragmatic approaches show a good understanding of speakers, concrete issues at stake, and situations they describe.

\subsection{Context, negotiation and dialogue processes in conflict, violence and reconciliation patterns}

Anthropologists and political scientists have stressed the importance of culture and language, especially when violence is involved, in markets, communities, societies, states and political organizations. Differences between binary (negotiation) and triadic (mediation, arbitration, adjudication) models of conflict resolution have been discussed in the literature since the sixties, following the debate between functional and cultural anthropology within the American and European traditions [31].

Contemporary post-war situations in the late $20^{\text {th }} \mathrm{c}$., in which mobs, mafias and private armies operate at a sub-state level, require new concepts to describe and explain them. Negotiation and peace processes in the absence of the state (in collapsed states and failed states) have fostered new refinements of the functions and types of mediators involved: explorer, convener, decoupler, unifier, enskiller, envisioner, guarantor, facilitator, legitimazer, enhancer, monitor, enforcer, reconciler [32].

Those functions are related to context and the level of escalation of conflict. Interestingly enough, in transitional justice - the complex aftermath of violent conflicts - it is not possible to face social justice in a simple way. Either in Perou, Argentina or the Czech Republic, in distant places with different times and actors, forms of relational justice are combined with a sort of community resilience, the exigency of public recognition of crimes, and punishment.

Taken from this point of view, negotiation and dialogue processes are not only produced through dialogical argumentation forms, but through complex social processes, in which even the most common categories - such as court and trialhave to be rebuild and implemented within a new political and economic environment. Kimberley Theidon, e.g., has been able to reconstruct recently one of such processes, carried out by peasant communities in the mountains of Perou after the defeat of Sendero Luminoso [33].

This kind of highly descriptive work, rooted in history and analysis of particular cases, has been taken into account, but left behind at the same time, in other fields with a different theoretical background. Problems such as the allocation of rights, the reckoning of the best strategic move, or the impact of conflict into the markets, lead to reduce the human and political complexity of possible scenarios to set forth theoretically manageable problems: reduction of actors to only two players, precise definition of cases, allocation of resources among competitive activities, difference between types of tactics and strategies in negotiation analysis according to hypothetic scenarios [34] [35] [36].

7 Focusing on the apologies in British English, Deutschmann carried out a corpus-based analysis on about 3.000 excuses contained in the BCNweb. He could not find any significant differences between men and women style of apologizing [30]. 
However, again, applied theory (either in international policy analysis, organization studies, management, or business analysis) introduces new levels of complexity to cope with real situations and explain the processes and outcomes of conflicts. Therefore, distributive (e.g. reckoning of compensation for a loss) and procedural justice (e.g. negotiation rules) are usually complemented with the socalled interactive justice (e.g. personal attitudes, emotional impact, communicative skills) [37], [38]. Some recent economic trends on intuition are following the old motto advanced by Herbert Simon: "Our task, you might say, is to discover the reason that underlies unreason" [39] [40].

\subsection{Theory and practice of mediation in law and legal systems}

Studies on mediation identify four different types of performing mediation: (i) facilitative (neutrality of mediator), (ii) evaluative (assistance and help offered to the parties to structure their position), (iii) transformative (mediator helps the parties to transform or change the situation), (iv) narrative (storytelling to get a new common version of what happened). Two-party bargaining is, since Raiffa's book, divided into two parts: distributive and integrative [34]. Sometimes a therapeutic style is distinguished from the narrative or the transformative ones, and a settlement-driven style is generally distinguished from a dialogue-driven (or transformative) one.

However, from an empirical point of view, when modeling epistemic situations (in business, markets, organizations or political arenas), a hybrid position is usually taken, because understanding situated strategic moves requires combining elements stemming from different classifications too. E.g., elements of power (pressure, sanctions...) combined with justice types, or social combined with procedural justice. Power always matters. ${ }^{8}$ To add complexity to the situation, a distinction may be made between regulatory and meta-regulatory strategies (regulation of regulation, regulation of law, regulation of access to justice initiatives) [41].

Mediators and negotiators use a particular professional language, and particular metaphors and folk concepts to handle cases and to refer to their own work. One of these most popular metaphors is window of opportunity. But there are more of them, related to situations where mediators intervene: cold or hot negotiation, in the shadow of the courts, get the hamster off the treadmill, being under the covers... [42].

In the eighties and nineties, this language and attitudes of mediators were challenged by legal scholars. Criticisms were thrown especially on the supposed 'neutrality' of the mediator. Maintaining such neutrality would lead to a paradox, because the intervention of non-intervention was viewed as untenable: a hidden agenda [43]. Actually, from this perspective, strategies like BATNA and practical books Getting to Yes can be easily seen as lawyers' manipulative intents to not loose control over the situation. ${ }^{9}$

\footnotetext{
${ }^{8}$ Aquino et al. put it in this way: “(...) power and justice are intertwined: one cannot really understand justice dynamics without understanding power dynamics and vice versa, because the concern for justice acts check on the use of power." [38]

${ }^{9}$ BATNA: Best Alternative To a Negotiated Agreement [44] [45]
} 
In recent times, proactive attitudes are considered more acceptable as a part of the process: the outcome is viewed as a result of the tension between mediator pressure and party autonomy [46]. Mediators themselves are aware of what they call "microlevel paradoxes"10, within a cooperative democratic framework (along with courts and the legal system) [47].

\section{Discussion and future research trends}

It is our contention that the language of Relational Justice is being produced not only through practice of ADR and ODR, but through the theoretical discourse and expanding work of all the scholars and reflective practitioners that try to sort out institutions and legal values from their practices and procedures. In this sense, there are two interesting issues to be faced. The first one is related to institutionalization: how to map the dialogic concepts, terms and techniques used in ADR into legal concepts and procedures so as to add value to the outcome of the mediation process. The second issue is how to grasp and preserve this type of RJ procedures and practices through the formal languages of the Semantic Web and W3.0. The use of technology clearly influences the use of mediation [48]. We agree with that.

In online mediation, capital letters are the online equivalent of shouting. ${ }^{11}$ Users sometimes mimic real face-to-face dialogues. But when the entire process is online, without the mediation of a real person (at least at the first steps), perhaps they don't. What should therefore be taken into account by electronic agents?

We have seen several types of variables -empathy, emotion, culture and professional practice, to summarize them - that cannot be ignored while taking a users-centered approach to ODR.

Perhaps the structure of online communication may alter the transformative side of mediation. But analysts of negotiation processes have noticed the power of reciprocation, the strong tendency to match another's person behavior [50]. This tendency acts in human-machine interfaces as well. As far as it has been researched, the Internet is not producing new kinds of emotions, but intensifies the existing ones [51]. The particular position of the machine may facilitate the empowerment of users and the balancing of emotions within rational communication (not out from it).

Quite recently, J. Zeleznikow, D. Walton and A. Lodder have proposed the use of a Rational Rule (RR) to act as a sort of cooperative conversational maxim between

10 "Mediators sometimes use what are known among psychotherapists as 'paradoxical interventions' to move the process along; that is, suggesting one thing while meaning another. For example, when we talk with a party who is hell-bent on proving her case in court, we might discuss all the advantages of a trial because the disadvantages would simply deepen her resistance to settlement." [44]

11 "I JUST WANT TO BE DONE WITH HER AND NEVER DEAL WITH HER AGAIN! LET'S JUST STOP ALL THE HASSLE AND RETURN MY MONEY! MANY, MANY THANKS!" [49] 
opponents. $^{12}$ [52] However, the proposal is presented in absolute terms, as replacing the paradigm of negotiation by the argumentation one. We cannot see why the RR inclusion should produce such a radical exclusion of negotiation moves, as they have been described by negotiation theorists.

Especially in difficult interactions, RR could be a helpful device if users decide to adopt an additional control over their own dialogue. The enactment of such a rule could be shared by both parties as well, and in this case we would not see negotiation and argumentation paradigms as mutually exclusive, but mutually inclusive. Argumentation devices and schemas could be modeled precisely to reach "coherent dialogues across incommensurable worlds". ${ }^{13}$

A pluralist approach to ODR implies respecting cultural constraints that users may have in their understanding of what are they doing through dialogue ${ }^{14}$, and giving them the opportunity to gain control over their own moves.

The idea of collaborative design is interesting too, and not incompatible with adding some rules to the argumentation process. Stemming from normative argumentation pragmatics, Aakhus describes the work of mediators as "communication by design", as they redirect, temporize and relativize the dialogue between disputants [56]. A pragmatic reconstruction of this "disagreement space", could help to build up useful tools for ODR purposes.

The last issue we would like to address deals with ontology construction. Dialogue and mediation is a conceptually well-trodden path [57]. There are works on ontology already done within the ecommerce field [58], collaborative tasks [59], negotiation [60] and negotiation agents [61]. There are some attempts to apply XML to mediation (the so-called Odr XML). ${ }^{15}$ And, of course, this book (LNAI 4884) has shown some interesting work on ODR ontological proposals (OPENKNOWLEDGE, BEST, ALIS). But, in general, the semantic richness of relational justice is not being captured yet. ODR is an open wide growing and promising field. We think that this is to be understood as a reason to incentivize future trends in this direction, because we believe that ODR ontologies are legal ontologies as well.

\section{Acknowledgments}

This work has been developed within the EU COST Action A21 Restorative Justice Developments in Europe. We did a great bulk of work during our stay at the CIRSFID and the ITTIG, in Bologna, in the summer of 2006. We warmly thank Giovanni Sartor, Giuseppe di Federico and Anna Mestitz for their kind reception and useful discussions.

12 " $(\mathrm{RR})$ When a proponent puts forward a valid argument with premises $\mathrm{P}=\left(\mathrm{P}_{1}, \mathrm{P}_{2} \ldots \mathrm{Pn}\right)$ that are all commitments of the respondent and conclusion $\mathrm{C}$, the respondent must, at the next move, either accept $\mathrm{C}$ or retract commitment to at least one of the premises P."

${ }^{13}$ Littlejohn and Domenici (2001), quoted in [53]. Actually, in the ODR environment proposed by Lodder and Zeleznikow within a three-step model, such an opposition between negotiation and argumentation is unnecesary [54].

${ }^{14}$ See [55] on the difference between Arabic and Hebrew concepts of what negotiation is. "To negotiate peace, rivals must agree on what is 'to negotiate' and what 'peace' is".

${ }^{15}$ We thank A.R. Lodder and J. Zeleznikow for this useful information. See http://www.oasisopen.org/committees/download.php/133/OdrXML\%20Charter\%202002.09.15\%201jk.doc . 


\section{References}

1. McCold, P.: Primary Restorative Justice Practices. In: Morris, A., Maxwell, G. (Eds.) Restorative Justice for Juveniles Conferencing, Mediation and Circles pp. 41-58. OxfordPortalnd, Hart Publishing (2001)

2. Singer, J., Makie, K., Hardy, T, Massie, G. (Eds.) The EU Mediation Atlas: Practice and Regulation. CEDR (2004)

3. Mestitz, A., Ghetti, S. (Eds.): Victim-offender Mediation with Youth Offenders in Europe. An overview and comparison of 15 countries. Springer, Dordrecht (2005)

4. Dignan, J., Marsh, P.: Restorative Justice and Family Group Conferences in England: Current State and Future Prospects. In: Morris, A., Maxwell, G. (Eds.) Restorative Justice for Juveniles Conferencing, Mediation and Circles pp. 85-101. Oxford-Portland, Hart Publishing (2001)

5. Casanovas, P. and Poblet, M.: Micro-foundations of restorative justice: a general framework. In: Mackay, R., Bošnjak, Deklerck, J., Pelikan, C., Stokkom, B., Wright, M. Images of Restorative Justice Theory, pp. 258. Verlag für Polizeiwissenschaft, Frankfurt am Main (2007)

6. de Bruijn, J., Ehring, M., Feier, C., Martín-Recuerda, F., Scharffe, F., Weiten, M.: Ontology Mediation, merging, and Aligning. In: Davies, J., Studer, R., Warren, P. (Eds.) Semantic Web Technologies. Trends and Research in Ontology-based Systems, pp. 95-113. John Wiley \& Sons, Ltd, Chichester (2006)

7. Aschoff, F.R., Schmalhofer, F., van Elst, L.: Knowledge Mediation: A Procedure for the Cooperative Construction of Domain Ontologies. In: Proceedings of the ECAI-2004 Workshop on Agent-mediated Knowledge Management (AMKM-2004), pp. 29-38 (2004)

8. Vrandečić, D, Pinto, S., Tempich, C., Sure, Y. The DILIGENT knowledge process. In: Journal of Knowledge Management, 9 (5), pp. 85-96 (2005)

9. Casanovas, P., Casellas, N., Tempich, C., Vrandečič, D., Benjamins, V.R. OPJK and DILIGENT: ontology modelling in a distributed environment. Artificial Intelligence and Law 15, 171-186 (2007)

10. Bailin, S.C., Truszowski, W : Ontology Negotiation: How Agents Can Really Get to Know Each Other. In: Truszkowski, Rouff, C., Hinchey, M. (Eds.) WRAC 2002, LNAI 2564, pp. 320-334, Springer, Heidelberg (2003)

11. Fehr, E., Camerer, C.F. : Social neuroeconomics: the neural circuitry of social preferences. TRENDS in cognitive science 11 (10), 419-227 (2007)

12. Bainbridge, W.S., Roco, M.C.: Manging Nano-Bio-Info-Cogno Innovations. Converging Technologies in Society. Springer, Heidelberg (2006)

13. Castelfranchi, C., Giardini, F., Marzo, M.: Relationships between rationality, human motives, and emotions. Mind \& Society, 5, pp. 173-197 (2006)

14. Aureli, F., de Waal, F.M.B. (eds.) Natural Conflict Resolution, University of California Press (2000)

15. de Waal, F.M.B.: Primates - A Natural Heritage of Conflict Resolution. Science, 289, july $28^{\text {th }}$, pp. $586-590(2000)$

16. Preston, S., de Waal, F.M.B.: Empathy: Its ultimate and proximal bases. Behavioral and Brain Sciences, 25, pp. 1-72 (2002)

17. Damasio, A.R. : The somatic marker hypothesis and the possible functions of the prefrontal cortex. Philosophical Transactions: Biological Sciences, 351, 1346,, pp. 1513-1420 (1996)

18. Singer, T., Frith, C.: The painful side of empathy, Nature Neuroscience 8 (7), pp. 845-846 (2005)

19. Fehr, E., Fischbacher, U., Gätcher, S.: Strong Reciprocity, Human Cooperation and the Enforcement of Social Norms, Human Nature, 13, pp. 1-25 (2002) 
20. Murray, R.J. : Forgiveness as a Therapeutic Option, The Family Journal: Counseling and Therapy for Couples and Families, 10,3, pp. 315-321 (2002).

21. McCullough, M.E., Rachal, K.C., Worthington Jr. E., Brown, S.W., Hight, T.L.: Interpersonal Forgiving in Close Relationships: II, Theoretical Elaboration and Measurement. Journal of Personality and Social Psychology. 75, 6, pp. 1586-1603 (1997).

22. Ekman, P.: Emotions Revealed. Understanding Faces and Feelings. Widenfield \& Nicholson, London (2003)

23. Nerlich, B., Clarke, D.D.: Semantic fields and frames: Historical explorations of the interface between language, action, and cognition, Journal of Pragmatics, 32, pp. 125-150 (2000)

24. Levinson, S.: Pragmatics. Cambridge University Press (1983)

25. Foley, W.A.: Anthropological Linguistics. An Introduction. Blackwell Publ., Oxford (1997)

26. Saville-Troike, M.: The Ethnography of Communication. An Introduction. Blackwell Publ., Oxford (2003)

27. Blum-Kulka, S., House, J., Kasper, G.: Cross-cultural pragmatics: Requests and Apologies, Ablex, Norwood, NJ (1989)

28. Rumelhart, D.E., McClelland, J.L. and the PDP Research Group: Parallel Distributed Processing. Explorations in the Microstructure of Cognition. Vol. 1. Foundations. Vol. 2. Psychological and Biological Models, Cambridge, Mass., The MIT Press (1986)

29. Clancey, W.J., Sachs, P., Sierhus, M., Hoof, R.V.: Brahms: simulating practice for work systems design, International Journal of Human-Computer Studies, 49, pp. 831-865 (1998)

30. Deutschmann, M.: Apologising in British English, Doctoral Dissertation. Skrifter från moderna språk 10. Institutionen för moderna språk, Umeå Universitet (2003)

31. Nader, L. (ed.) Law in Culture and Society. Aldine Publ., Chicago (1969)

32. Lederach, P.: Building Peace. Sustainable Reconciliation in Divided Societies. United States Institute of Peace Press, Washington, (1997)

33. Theidon, K.: Justice in Transition. The Micro-politics of Reconciliation in Postwar Peru, Journal of Conflict Resolution, 50/3, pp. 433-457 (2006)

34. Raiffa, H. The Art and Science of Negotiation. Cambridge Mass., Harvard University Press (1982

35. Garfinkel, M.R., Skarpedas, S.: Economics of Conflict: An Overview. University of California (Irvine) http://ideas.repec.org/p/irv/wpaper/050623.html (2006)

36. Yiu, K.T.W., Cheng, C.O. A Study of Construction Mediator Tactics. Part II: The Contiongent Use of Tactics, Building and Environment, 42, I2, pp. 752-761 (2007)

37. Chebat, J.C., Slusarczyk, W.: How emotions mediate the effects of perceived justice on loyalty in service recovery situations. Journal of Business Research, 58, pp. 664-673 (2005)

38. Aquino, K., Tripp, T., Bies, R.J.: Getting Even or Moving On? Power, procedural Justice, and Types of Offenses as Predictors of Revenge, Forgiveness, Reconciliation, and Avoidance in Organizations. Journal of Applied Psychology, 91, 3, pp. 653-668 (2006)

39. Simon, H.A.: Making Management Decisions:The Role of Intuition and Emotion, Academy of Management Executive, February, pp. 57-64 (1987)

40. Kahnemann, Daniel. Maps of Bounded Rationality: Psychology for Behavioral Economics. The American Economic Review, 5, pp. 1449-1475 (2003)

41. Braithwaite, J. Meta-regulation for Access to Justice: Presentation to General Aspects of Law (GALA). Seminar series, University of California, Berkeley, November $13^{\text {th }}(2003)$ http://www.law.berkeley.edu/centers/kadish/gala03/Braithwaite\%20Kent.pdf

42. Jameson, J.K.; Bodtker, A.M; Jone, T.: Like Talking in a Brick Wall: Implications of Emotion Metaphors for Mediation Practice, Negotiation Journal, 22, 2, April, pp. 199-207 (2006)

43. Cobb, S.; Rifkin, J.: Practice and Paradox: Deconstructing neutrality in Mediation. Law and Social Inquiry, 16,1, , pp. 36-62 (1991) 
44. Fisher, R.; Ury, W.: Getting to Yes. Negotiating Agreement Without Giving In. Houghton Mifflin Company (1981)

45. Fisher, R.; Shapiro, D.: Beyond Reason. Using Emotions as You Negotiate. Random House Business Books, (2006)

46. Hoffman, D. : Paradoxes of Mediation, American Association Dispute Resolution Magazine, Fall/Winter (2002) Reprinted: http://bostonlawcollaborative.com/documents/2005-07-paradoxes-of-mediation.pdf (2005)

47. Olson, S.M. and Dzur, A.W.: Revisiting Informal Justice: Restorative Justice and Democratic Professionalism, Law \& Society Review, 38, 1, pp. 139-176, (2004)

48. Uijjttenbroek, E.M.: The influence of motives and styles in mediation online dispute resolution. In: Lodder, A., Rule, C., Zeleznikow, J. Proceedings of 4rt International Workshop on ODR. Palo Alto, June $8^{\text {th }}$, pp. 31-35 (2007)

49. Raines, S.S. Can Online Mediation Be Transformative? Tales From the Front. Conflict Resolution Quarterly, 22, 4, pp. 437-451 (2005)

50. De Dreu, C.K.W.; Carnevale, P.J.: Disparate Methods and Common Findings in the Study of Negotiation, International negotiation, 10, pp. 193-203 (2005)

51. Ben-Ze'ev, A.: Privacy, emotional closeness, and openness in cyberspace. Computers in Human Behavior 19 , pp. 451-467 (2003).

52. Walton, D. ; Zeleznikow, J.; Lodder, A. : What Role can Rational Argument Play in ADR and Online Dispute Resolution. Second International ODR Workshop, Wolf Legal Publishers, Tilburg (2005)

53. Putnam, L.: Transformations and Critical Moments in Negotiations, Negotiation Journal, 20,2, April, pp. 275-295 (2004)

54. Lodder, A.R.; Zeleznikow, J.: Developing an Online Dispute Resolution Environment: Dialogue Tools and Negotiation Support Systems in a Three-Step Model. Harvard Negotiation Law Review 10, pp. 288-237 (2005)

55. Cohen, R.: Negotiating Across Cultures, 2nd ed., Washington DC, U.S. Institute for Peace (1997)

56. Aakhus, M. :Neither Naïve nor Critical Reconstruction: Dispute Mediators, Impasse, and the Design of Argumentation. Argumentation, 17, pp. 265-290 (2003)

57. See: Walton, D. The place of Dialogue Theory in Logic, Computer Science and Communication Studies. Synthese, 123, pp. $327-346$ (2000); Gordon, T., Märker, O. Mediation Systems, Online mediation (2002). Neue Medien in Der Konfliktvermittung-Mit Bespielen Aus Politik Und Wirtschaft., in OlMärker and Trénel (eds.) Edition Sigma, Berlin, pp. 61-84 (2002); Thiessen, E., Zeleznikow, J. Technical Aspects of Online Dispute Resolution-Challenges and Opportunities, http://www.odr.info/unforum2004/thiessen zeleznikow.htm; Sartor, G. A Teleological Approach to Legal Discourses, EUI WP LAW n. 28 (2006); Katsh, E. Online Dispute Resolution: Some Implications for the Emergence of Law in Cyberspace, International Review of Law Computers \& Technology, 21, 2, pp. 97-107 (2007)

58. Tamma, V., Phelps, S., Dickinson, I., Wooldridge, M. Ontologies for supporting negotiation in e-commerce, Engineering Applications of Artificial Intelligence, 18, pp. 223$236(2005)$

59. Ermolayev, V., Keberle, N., Tolok, V. OIL Ontologies for Collaborative Task Performance in Coalitions of Self-Interested Actors, ER 2001 Workshops, LNAI 2465, pp. 390-402 (2002)

60. Anumba, C.J., Ren, Z., Thorpe, A., Ugwu, O.O., Newnham, L. Negotiation within a multiagent system for the collaborative design of light industrial buildings, Advances in Engineering Software, 34, pp. 389-401 (2003)

61. Bailin, S.C., Truszkowski, W. Ontology Negotiation Between Intelligent Information Systems, The Knowledge Engineering Review, 17, 1, pp. 7-19 (2002); 


\section{Appendix: Tables}

Table 1. Basic empirical research on mind, language, empathy and emotions.

\begin{tabular}{|c|c|c|c|c|}
\hline Fields & Authors & Focus & Object & Methodology \\
\hline Social Neuroscience & $\begin{array}{l}\text { Farrow, Clark } \\
\text { Lawrence } \\
\text { Singer, Saxe } \\
\text { Damasio } \\
\text { LeDoux, Harris, } \\
\text { Iacoboni, Preston }\end{array}$ & $\begin{array}{l}\text { Brain and neural } \\
\text { functioning }\end{array}$ & $\begin{array}{l}\text { Empathy and } \\
\text { emotions } \\
\text { (forgiveness) in brain } \\
\text { areas. Somatic } \\
\text { markers hypothesis } \\
\text { (SMH). }\end{array}$ & $\begin{array}{l}\text { Controlled lab } \\
\text { experiments, } \\
\text { Functional MRI } \\
\text { (fMulti Image } \\
\text { Ressonance) }\end{array}$ \\
\hline Cognitive Science & $\begin{array}{l}\text { Gardner } \\
\text { Minsky } \\
\text { Rumelhart } \\
\text { McClelland } \\
\text { Hollan, } \\
\text { Hutchins,Thagard }\end{array}$ & $\begin{array}{l}\text { Intelligence and } \\
\text { social behavior }\end{array}$ & $\begin{array}{l}\text { ToM (Theory of } \\
\text { Mind). Scripts and } \\
\text { cognitive patterns in } \\
\text { social cognition }\end{array}$ & $\begin{array}{l}\text { Neural networks, } \\
\text { scripts, cognitive } \\
\text { modeling }\end{array}$ \\
\hline Primatology & $\begin{array}{l}\text { De Waal, Aureli } \\
\text { Flack, Cords } \\
\text { Schaffner }\end{array}$ & $\begin{array}{l}\text { Aggression and } \\
\text { conciliatory } \\
\text { behavior }\end{array}$ & $\begin{array}{l}\text { Empathy and } \\
\text { cooperative } \\
\text { interaction patterns in } \\
\text { monkeys, apes and } \\
\text { humans. Relational } \\
\text { model of aggression. }\end{array}$ & $\begin{array}{l}\text { Behavioral } \\
\text { observation, social } \\
\text { networks, distance } \\
\text { analysis, kinship, } \\
\text { social niches } \\
\text { reconstruction }\end{array}$ \\
\hline $\begin{array}{l}\text { Basic Social } \\
\text { Psychology Research }\end{array}$ & $\begin{array}{l}\text { Ekman, Rolls } \\
\text { Lazarus } \\
\text { Bandura, Ortony, } \\
\text { Gallup }\end{array}$ & $\begin{array}{l}\text { Categorization, } \\
\text { basic emotions and } \\
\text { communicative } \\
\text { behavior }\end{array}$ & $\begin{array}{l}\text { Conceptual } \\
\text { representation, } \\
\text { empathy and universal } \\
\text { (basic) emotions in } \\
\text { human expression } \\
\text { (bodily and linguistic) }\end{array}$ & $\begin{array}{l}\text { Neural networks, } \\
\text { controlled lab } \\
\text { experiments, } \\
\text { genetics, regression } \\
\text { analysis, } \\
\text { prototype and } \\
\text { semantic analysis }\end{array}$ \\
\hline
\end{tabular}

Table 2. Applied social psychology on empathy, forgiveness, apologies and evaluation.

\begin{tabular}{|c|c|c|c|c|}
\hline Fields & Authors & Focus & Object & Methodology \\
\hline $\begin{array}{l}\text { Social Psychology, } \\
\text { Therapy and } \\
\text { Counseling }\end{array}$ & $\begin{array}{l}\text { Enright, } \\
\text { McCullough } \\
\text { Barber, Allan } \\
\text { Worthington } \\
\text { Wade, Rye } \\
\text { Kearns, Franz } \\
\text { Jolliffe, Petrucci } \\
\text { Mcpherson } \\
\text { Finchman } \\
\text { Mullet, Murray }\end{array}$ & $\begin{array}{l}\text { Forgiveness, guilt, } \\
\text { shame and basic } \\
\text { emotions in } \\
\text { interactions, family } \\
\text { situations and } \\
\text { collective behavior }\end{array}$ & $\begin{array}{l}\text { Empathy, } \\
\text { faceworking, } \\
\text { forgiveness, apology, } \\
\text { revenge and } \\
\text { avoidance patterns in } \\
\text { conflict, post-conflict } \\
\text { situations and } \\
\text { mediation. }\end{array}$ & $\begin{array}{l}\text { Controlled lab } \\
\text { experiments, tests, } \\
\text { descriptive } \\
\text { statistics, regression } \\
\text { analysis, evaluation } \\
\text { scales (TRIM, } \\
\text { PTRIM), prototype } \\
\text { analysis }\end{array}$ \\
\hline $\begin{array}{l}\text { Social Psychology } \\
\text { and Narrative } \\
\text { Analysis }\end{array}$ & $\begin{array}{l}\text { Baumeister } \\
\text { Zeichmeister } \\
\text { Stillwell } \\
\text { Schütz } \\
\text { Leith Romero }\end{array}$ & $\begin{array}{l}\text { Narratives by } \\
\text { victims and } \\
\text { offenders }\end{array}$ & $\begin{array}{l}\text { Identity and roles. } \\
\text { Speech and writing } \\
\text { patterns expressing } \\
\text { emotions (shame and } \\
\text { guilt) }\end{array}$ & $\begin{array}{l}\text { Textual and } \\
\text { narrative analysis, } \\
\text { rol games, } \\
\text { controlled lab } \\
\text { experiments. }\end{array}$ \\
\hline $\begin{array}{l}\text { Social Psychology } \\
\text { and Criminology }\end{array}$ & $\begin{array}{l}\text { Strang } \\
\text { Maxwell } \\
\text { Morris } \\
\text { Sherman } \\
\text { Karremans } \\
\text { Bayley } \\
\text { Robbins Arrigo } \\
\text { Darley, Harris } \\
\text { Hay, Kressel } \\
\text { van den Boss }\end{array}$ & $\begin{array}{l}\text { VOM/RJ } \\
\text { evaluation, } \\
\text { recidivism, } \\
\text { victim-offender } \\
\text { attitudes. } \\
\text { Juveniles. Divorce. }\end{array}$ & $\begin{array}{l}\text { Personality factors, } \\
\text { family disorders, } \\
\text { violence, restoration } \\
\text { effects. }\end{array}$ & $\begin{array}{l}\text { Evaluation analysis. } \\
\text { Indexes, scales. } \\
\text { Regression } \\
\text { analysis. Meta- } \\
\text { analysis. }\end{array}$ \\
\hline
\end{tabular}


Table 3. Applied linguistic research on politeness, apologies, excuses and cultural contexts.

\begin{tabular}{|c|c|c|c|c|}
\hline Fields & Authors & Focus & Object & Methodology \\
\hline $\begin{array}{l}\text { Frame Semantics } \\
\text { and Cognitive } \\
\text { Linguistics }\end{array}$ & $\begin{array}{l}\text { Fillmore, Lakoff, } \\
\text { Johnson }\end{array}$ & $\begin{array}{l}\text { Structure of } \\
\text { meaning encoding } \\
\text { pragmatic and } \\
\text { encyclopedic } \\
\text { knowledge }\end{array}$ & $\begin{array}{l}\text { Frames, scripts, } \\
\text { prototypes behind } \\
\text { lexical groups of } \\
\text { words. Rhetorical } \\
\text { devices esp. metaphor. }\end{array}$ & $\begin{array}{l}\text { Linguistic } \\
\text { phenomenology, } \\
\text { prototype analysis }\end{array}$ \\
\hline $\begin{array}{l}\text { Linguistics and } \\
\text { Cross-cultural } \\
\text { Pragmatics }\end{array}$ & $\begin{array}{l}\text { Tannen, } \\
\text { Wierzwicka, } \\
\text { Blum-Kulka, } \\
\text { Nelson, } \\
\text { Rojo } \\
\text { Risako, } \\
\text { Liebersohn } \\
\end{array}$ & $\begin{array}{l}\text { Cultural } \\
\text { competence and } \\
\text { linguistic } \\
\text { assumptions within } \\
\text { social behavior }\end{array}$ & $\begin{array}{l}\text { Discourse, and event } \\
\text { and speech acts in } \\
\text { apologies and excuses } \\
\text { in diverse cultural } \\
\text { contexts and natural } \\
\text { languages }\end{array}$ & $\begin{array}{l}\text { Linguistic } \\
\text { phenomenology, } \\
\text { comparative data } \\
\text { analysis, }\end{array}$ \\
\hline $\begin{array}{l}\text { Linguistics and } \\
\text { Functional } \\
\text { Pragmatics }\end{array}$ & $\begin{array}{l}\text { Tannen, } \\
\text { Fraser, Jacobs } \\
\text { Heisterkamp, } \\
\text { Glover Holmes } \\
\text { Stewart }\end{array}$ & $\begin{array}{l}\text { Pragmatic and } \\
\text { linguistic } \\
\text { competence in } \\
\text { verbal and non- } \\
\text { verbal interactions }\end{array}$ & $\begin{array}{l}\text { Frames, code- } \\
\text { switching, distal } \\
\text { deixis, contextual- } \\
\text { cues, in apologies, } \\
\text { negotiation and } \\
\text { mediation sessions }\end{array}$ & $\begin{array}{l}\text { Linguistic } \\
\text { phenomenology, } \\
\text { transcript and } \\
\text { videotape analysis }\end{array}$ \\
\hline $\begin{array}{l}\text { Sociolinguistics, } \\
\text { Discourse Analysis } \\
\text { and Corpus-based } \\
\text { analysis }\end{array}$ & $\begin{array}{l}\text { Brown, Levinson, } \\
\text { Deutchsmann, } \\
\text { Davies, Márquez } \\
\text { Meier }\end{array}$ & $\begin{array}{l}\text { Politeness, social } \\
\text { and linguistic and } \\
\text { pragmatic rules in } \\
\text { social behavior }\end{array}$ & $\begin{array}{l}\text { Idiolects. Sociolects. } \\
\text { Structure, types and } \\
\text { functions of excuses } \\
\text { and apologies in } \\
\text { verbal sequences in } \\
\text { natural language } \\
\text { (English, Spanish...) }\end{array}$ & $\begin{array}{l}\text { Linguistic } \\
\text { phenomenology, } \\
\text { descriptive } \\
\text { statistics, data- } \\
\text { bases organization } \\
\text { methods, prototype } \\
\text { analysis }\end{array}$ \\
\hline
\end{tabular}

Table 4. Sociological research on micro-situations, cognition, emotions and discourse.

\begin{tabular}{|l|l|l|l|l|}
\hline Fields & Authors & Focus & Object & Methodology \\
\hline $\begin{array}{l}\text { Micro or } \\
\text { Sociology }\end{array}$ & $\begin{array}{l}\text { Simmel, } \\
\text { Goffman, Scheff, } \\
\text { Retzinger }\end{array}$ & $\begin{array}{l}\text { Social emotions in } \\
\text { interactions. } \\
\text { Violence cycles } \\
\text { and social } \\
\text { structure. }\end{array}$ & $\begin{array}{l}\text { Face-working and } \\
\text { human interaction } \\
\text { patterns: shame as a } \\
\text { social bond }\end{array}$ & $\begin{array}{l}\text { Participant } \\
\text { observation, } \\
\text { ethnography, } \\
\text { interviews, } \\
\text { conceptual } \\
\text { modeling. }\end{array}$ \\
\hline $\begin{array}{l}\text { Ethnomethodology, } \\
\text { Discourse and } \\
\text { Conversational } \\
\text { Analysis }\end{array}$ & $\begin{array}{l}\text { Garfinkel, } \\
\text { Goodwin, Antaki } \\
\text { Garcia Greatbach } \\
\text { Dingwall } \\
\text { Presser } \\
\text { Lowerkamp }\end{array}$ & $\begin{array}{l}\text { Discourse } \\
\text { sequences, turn } \\
\text { talking, adjancy } \\
\text { pairs, code- } \\
\text { switching }\end{array}$ & $\begin{array}{l}\text { Argumentative talking } \\
\text { patterns and situated } \\
\text { cognition }\end{array}$ & $\begin{array}{l}\text { Audio and } \\
\text { videotaping, } \\
\text { transcript data } \\
\text { analysis, discourse } \\
\text { and cognitive } \\
\text { analysis, conceptual } \\
\text { modeling }\end{array}$ \\
\hline Cognitive Sociology & $\begin{array}{l}\text { Cicourel } \\
\text { Engeström } \\
\text { Middleton } \\
\text { Edwards }\end{array}$ & $\begin{array}{l}\text { Social distributed } \\
\text { cognition in } \\
\text { organizations, } \\
\text { institutions and } \\
\text { workplaces }\end{array}$ & $\begin{array}{l}\text { Situated meaning: } \\
\text { explicit and implicit } \\
\text { assumptions in } \\
\text { interaction patterns }\end{array}$ & $\begin{array}{l}\text { Audio and } \\
\text { videotaping, } \\
\text { transcript data } \\
\text { analysis, discourse } \\
\text { and cognitive } \\
\text { analysis }\end{array}$ \\
\hline
\end{tabular}


Table 5. Research on social and political violence, conflict resolution, reconciliation, allocation of resources and rights, and neural bases of preferences.

\begin{tabular}{|c|c|c|c|c|}
\hline Fields & Authors & Focus & Object & Methodology \\
\hline $\begin{array}{l}\text { Anthropology and } \\
\text { Conflict Resolution }\end{array}$ & $\begin{array}{l}\text { Bateson, } \\
\text { Nader } \\
\text { Greenhouse } \\
\text { Lederach } \\
\text { Roberts } \\
\text { Theidon } \\
\text { Davidheiser }\end{array}$ & $\begin{array}{l}\text { Violence and } \\
\text { reconciliation in } \\
\text { communities and } \\
\text { societies }\end{array}$ & $\begin{array}{l}\text { Transitional justice, } \\
\text { forgiveness and } \\
\text { reconciliation patterns }\end{array}$ & $\begin{array}{l}\text { Ethnography, history, } \\
\text { narrative analysis, } \\
\text { conceptual modeling }\end{array}$ \\
\hline $\begin{array}{l}\text { Communication and } \\
\text { Intercultural } \\
\text { Conflict Studies }\end{array}$ & $\begin{array}{l}\text { Hammer, Ting- } \\
\text { Toomey } \\
\text { Oetzel } \\
\text { Kurogi } \\
\text { Van Ginkel Goto } \\
\text { Chan Trubisnky }\end{array}$ & $\begin{array}{l}\text { Cultural } \\
\text { competence in } \\
\text { inter-ethnic } \\
\text { conflicts. }\end{array}$ & $\begin{array}{l}\text { Conflict resolution } \\
\text { styles in individualist } \\
\text { and collectivist } \\
\text { cultures. }\end{array}$ & $\begin{array}{l}\text { Factor analysis, } \\
\text { regression, focus } \\
\text { groups, conceptual } \\
\text { modeling }\end{array}$ \\
\hline $\begin{array}{l}\text { Political Science, } \\
\text { Conflict Resolution } \\
\text { and International } \\
\text { Relations Studies }\end{array}$ & $\begin{array}{l}\text { Berkowitz, } \\
\text { David, Choi } \\
\text { Didier, Marret } \\
\text { Lefranc, Minow }\end{array}$ & $\begin{array}{l}\text { Inter, intra and } \\
\text { infra-state } \\
\text { conflicts }\end{array}$ & $\begin{array}{l}\text { Policy, transitional } \\
\text { justice and peace } \\
\text { processes }\end{array}$ & $\begin{array}{l}\text { Game theory, social } \\
\text { networks, history, } \\
\text { regression and path } \\
\text { analysis, conceptual } \\
\text { modeling }\end{array}$ \\
\hline $\begin{array}{l}\text { Economics and } \\
\text { Conflict Resolution }\end{array}$ & $\begin{array}{l}\text { Arrow, Raiffa, } \\
\text { Axelrod, } \\
\text { Harsanyi, } \\
\text { Garfinkel, Fehr }\end{array}$ & $\begin{array}{l}\text { Allocation of } \\
\text { resources, effects } \\
\text { of conflict on } \\
\text { economic } \\
\text { outcomes, } \\
\text { property rights, } \\
\text { neurological bases }\end{array}$ & $\begin{array}{l}\text { Policy, competitive } \\
\text { decision making, } \\
\text { cooperative behavior, } \\
\text { theory of complexity, } \\
\text { neuroeconomics }\end{array}$ & $\begin{array}{l}\text { Game theory, choice } \\
\text { theory, optimization } \\
\text { techniques } \\
\text { statistics,probabilistic } \\
\text { calculus, axiomatic } \\
\text { models }\end{array}$ \\
\hline
\end{tabular}

Table 6. Empirical and theoretical research on dialogue, argumentation, negotiation, and mediation.

\begin{tabular}{|c|c|c|c|c|}
\hline Fields & Authors & Focus & Object & Methodology \\
\hline $\begin{array}{l}\text { Argumentation and } \\
\text { Dialogue }\end{array}$ & $\begin{array}{l}\text { Walton, van } \\
\text { Eemeren, Jacobs, } \\
\text { Grootendors, } \\
\text { Jackson, Prakken } \\
\text { Sartor, Lodder }\end{array}$ & $\begin{array}{l}\text { Practical and } \\
\text { dialectical } \\
\text { reasoning }\end{array}$ & $\begin{array}{l}\text { Inferences, chains and } \\
\text { arguments. Induction, } \\
\text { deduction and } \\
\text { abduction. }\end{array}$ & $\begin{array}{l}\text { First order, modal } \\
\text { and non-monotonic } \\
\text { logic, observation, } \\
\text { conceptual } \\
\text { modeling (dialectic } \\
\text { systems) }\end{array}$ \\
\hline Negotiation Studies & $\begin{array}{l}\text { Carnevale } \\
\text { De Moor } \\
\text { Cobb, Ross } \\
\text { Putnam } \\
\text { Kolb, Botker } \\
\text { Jameson,Dewulf, } \\
\text { Karsten, Curhan, } \\
\text { van Merode }\end{array}$ & $\begin{array}{l}\text { Communication } \\
\text { and strategic } \\
\text { behavior in } \\
\text { mediation and } \\
\text { dispute resolution }\end{array}$ & $\begin{array}{l}\text { Agreement, } \\
\text { settlement-driven } \\
\text { processes. Strategic } \\
\text { and tactic moves }\end{array}$ & $\begin{array}{l}\text { Game theory, } \\
\text { descriptive } \\
\text { statistics, focus } \\
\text { groups, participant } \\
\text { observation, } \\
\text { narrative analysis }\end{array}$ \\
\hline $\begin{array}{l}\text { Management and } \\
\text { Organization Studies }\end{array}$ & $\begin{array}{l}\text { Simon, Chen, Yiu } \\
\text { Cheung, } \\
\text { Bradfield, Chebat } \\
\text { Aquino, Benoit } \\
\text { Tomlison } \\
\text { Dörrenbächer } \\
\end{array}$ & $\begin{array}{l}\text { Decision making } \\
\text { in workplaces and } \\
\text { organizations. } \\
\text { Communication } \\
\text { inter and intra- } \\
\text { organizations. }\end{array}$ & $\begin{array}{l}\text { Trust repair, image } \\
\text { repair, } \\
\text { organizational design, } \\
\text { conflict management } \\
\text { and tactic behavior }\end{array}$ & $\begin{array}{l}\text { AI design, } \\
\text { regression analysis, } \\
\text { game and bounded } \\
\text { rationality analysis, } \\
\text { conceptual } \\
\text { modeling }\end{array}$ \\
\hline $\begin{array}{l}\text { Applied Artificial } \\
\text { Intelligence }\end{array}$ & $\begin{array}{l}\text { Zeleznikow, } \\
\text { Katsh, Bench- } \\
\text { Capon, Wyner } \\
\text { Bellucci, Nitta } \\
\text { Aakhus, Aldrich } \\
\text { Tzeng, Gordon } \\
\text { Ben-Ze'ev } \\
\text { Castelfranchi } \\
\end{array}$ & $\begin{array}{l}\text { Human-machine } \\
\text { interaction and } \\
\text { design }\end{array}$ & $\begin{array}{l}\text { Internet. } \\
\text { Computer/user } \\
\text { interface. On-line } \\
\text { Dispute Resolution } \\
\text { (ODR). Multiple- } \\
\text { Agent Systems (MAS) }\end{array}$ & $\begin{array}{l}\text { Program design, } \\
\text { game theory, } \\
\text { program } \\
\text { implementation } \\
\text { cycles, conceptual } \\
\text { modeling }\end{array}$ \\
\hline
\end{tabular}


Table 7. Criminological and judiciary research on practices and outcomes of mediation and VOM.

\begin{tabular}{|c|c|c|c|c|}
\hline Fields & Authors & Focus & Object & Methodology \\
\hline Criminology & $\begin{array}{l}\text { Christie, Wall, } \\
\text { van Stokkom, } \\
\text { Daly, Pelikan, } \\
\text { Cohen, Dignan, } \\
\text { Mika, Young, } \\
\text { Bazemore, de } \\
\text { Haan, Strang, } \\
\text { Cohen, Morris }\end{array}$ & $\begin{array}{l}\text { Practices of VOM, } \\
\text { Mediation, } \\
\text { Juvenile justice, } \\
\text { Conferencing }\end{array}$ & $\begin{array}{l}\text { RJ outcomes and } \\
\text { processes. Low and } \\
\text { severe crimes. } \\
\text { Juvenile and gendered } \\
\text { violence/ restoration. }\end{array}$ & $\begin{array}{l}\text { Participant } \\
\text { observation, } \\
\text { surveys, descriptive } \\
\text { statistics, } \\
\text { ethnography, meta- } \\
\text { analysis }\end{array}$ \\
\hline $\begin{array}{l}\text { Social Work and } \\
\text { Professional } \\
\text { Mediators' Studies }\end{array}$ & $\begin{array}{l}\text { Umbreit, Vos } \\
\text { Coates, McCold } \\
\text { Démaret, } \\
\text { MacKay, } \\
\text { Schroeder } \\
\text { Hofman, Raines } \\
\text { Coppola, Tyler } \\
\text { Crossland,Sousa }\end{array}$ & $\begin{array}{l}\text { Professional } \\
\text { counseling, } \\
\text { policing, and } \\
\text { practice }\end{array}$ & $\begin{array}{l}\text { Mediation processes } \\
\text { and outcomes. } \\
\text { Tactics, strategies, } \\
\text { cases. }\end{array}$ & $\begin{array}{l}\text { Reflective practice, } \\
\text { case analysis, } \\
\text { professional } \\
\text { experience } \\
\text { accounts, } \\
\text { descriptive } \\
\text { statistics. }\end{array}$ \\
\hline $\begin{array}{l}\text { Comparative RJ and } \\
\text { Judicial Studies }\end{array}$ & $\begin{array}{l}\text { Miers, Martin, } \\
\text { Willensems, } \\
\text { Mestitz,Getti, } \\
\text { Aertsen, } \\
\text { Deklerck, } \\
\text { Vanfraenchem }\end{array}$ & $\begin{array}{l}\text { RJ organization } \\
\text { and practice. } \\
\text { Linkage to judicial } \\
\text { settings and } \\
\text { administrative } \\
\text { settings. }\end{array}$ & $\begin{array}{l}\text { Functional anchorage } \\
\text { of RJ (juveniles, } \\
\text { VOM, mediation) into } \\
\text { legal and judicial } \\
\text { systems in national } \\
\text { countries. }\end{array}$ & $\begin{array}{l}\text { Semi-structured and } \\
\text { in-deep interviews, } \\
\text { surveys, descriptive } \\
\text { statistics, } \\
\text { comparative } \\
\text { organizational data } \\
\text { analysis }\end{array}$ \\
\hline
\end{tabular}

Table 8. Legal, social, political and philosophical framework (Rule of Law) for rights and values.

\begin{tabular}{|c|c|c|c|c|}
\hline Fields & Authors & Focus & Object & Methodology \\
\hline Socio-legal studies & $\begin{array}{l}\text { Olson, Dzur } \\
\text { Roche, Faget } \\
\text { Bonnafé-Schmitt } \\
\text { Lemley, Hudson, } \\
\text { Hoffmann, } \\
\text { Morrill, } \\
\text { Morrison, Resta }\end{array}$ & $\begin{array}{l}\text { Regulation, } \\
\text { transformation of } \\
\text { law, policy, legal } \\
\text { anchored } \\
\text { mediation and } \\
\text { professional work }\end{array}$ & $\begin{array}{l}\text { Institutionalization of } \\
\text { RJ practices in a } \\
\text { globalized world. } \\
\text { Deliberative } \\
\text { democracy, } \\
\text { governance and law }\end{array}$ & $\begin{array}{l}\text { Legal, political and } \\
\text { socio-legal } \\
\text { modeling. Meta- } \\
\text { analysis. }\end{array}$ \\
\hline $\begin{array}{l}\text { Legal Theory, Rights } \\
\text { and Jurisprudence }\end{array}$ & $\begin{array}{l}\text { Zehr, Braithwaite } \\
\text { Walgrave, van } \\
\text { Ness, von Hirsh, } \\
\text { Hartmann, } \\
\text { Bosnjak, } \\
\text { Ashworth } \\
\text { Johnstone } \\
\text { Beristain } \\
\text { Reimund }\end{array}$ & $\begin{array}{l}\mathrm{RJ} \text { as a general } \\
\text { transforming } \\
\text { model }\end{array}$ & $\begin{array}{l}\text { Reflection on the RJ } \\
\text { political and legal } \\
\text { paradigm. Role and } \\
\text { function of RJ within } \\
\text { changing Rule of Law } \\
\text { models. }\end{array}$ & $\begin{array}{l}\text { Legal design, } \\
\text { rights' discourse, } \\
\text { legal, criminal and } \\
\text { political } \\
\text { argumentation. } \\
\text { Normative analysis }\end{array}$ \\
\hline $\begin{array}{l}\text { Philosophy and } \\
\text { Ethics }\end{array}$ & $\begin{array}{l}\text { Wright, Elster, } \\
\text { Nussbaum, } \\
\text { Bennett } \\
\text { Smith }\end{array}$ & $\begin{array}{l}\text { Distributive } \\
\text { justice, restorative } \\
\text { justice, and moral } \\
\text { values }\end{array}$ & $\begin{array}{l}\text { Justice within } \\
\text { socioeconomic and } \\
\text { political models }\end{array}$ & Normative analysis \\
\hline
\end{tabular}

